\title{
A Case of Cranial Fasciitis in Midface
}

\author{
Jungkyu Cho ${ }^{1}$, Hankyeol Kim ${ }^{1}$, Yoon Kyoung So ${ }^{2}$, and Sang Duk Hong ${ }^{1}$ \\ ${ }^{1}$ Department of Otorhinolaryngology-Head and Neck Surgery, Samsung Medical Center, Sungkyunkwan University School of Medicine, \\ Seoul; and ${ }^{2}$ Department of Otolaryngology, Ilsan Paik Hospital, Inje University College of Medicine, Goyang, Korea
}

\section{안면 중앙부에 발생한 두개 근막염 1예}

\author{
조정규 ${ }^{1} \cdot$ 김한결 $^{1} \cdot$ 소윤경 ${ }^{2} \cdot$ 홍상덕 $^{1}$ \\ 성균관대학교 의과대학 삼성서울병원 이비인후과학교실, ${ }^{1}$ 인제대학교 의과대학 일산백병원 이비인후과학교실 ${ }^{2}$
}

Received March 2, 2015

Revised March 31, 2015

Accepted April 16, 2015

Address for correspondence

Sang Duk Hong, MD

Department of Otorhinolaryngology-

Head and Neck Surgery,

Samsung Medical Center,

Sungkyunkwan University

School of Medicine,

81 Irwon-ro, Gangnam-gu,

Seoul 06351, Korea

Tel +82-2-3410-3579

Fax +82-2-3410-3879

E-mail kkam97@gmail.com
Cranial fasciitis is an uncommon subset of nodular fasciitis composed of spindle cells and myxoid stroma. This is not considered as a true neoplasm, as it occurs mostly in the scalp as a rapidly growing mass accompanied by adjacent bony structure destruction. There are few cases of cranial fasciitis reported in the literature; however, we experienced a case of a 2-yearold girl with swelling of midface. Subtotal resection was performed and the final pathological result confirmed cranial fasciitis. We report this rare case with a review of the literature. Korean J Otorhinolaryngol-Head Neck Surg 2015;58(11):786-92

Key Words Cranial fasciitis · Midface $\cdot$ Nodular fasciitis $\cdot$ Spindle cell.

\section{서 론}

두개 근막염은 어린 소아의 두피 및 두개골에 발생하는 섬 유모세포 기원의 희귀한 양성 병변으로 성인에서 사지에 발생 하는 결절성 근막염과 조직학적으로 동일하나 발생 부위, 호 발 연령과 임상양상의 차이를 보인다. 두개 근막염은 1980년 도에 Lauer와 Enzinger ${ }^{1}$ 가 9예를 처음 보고하였는데, 소아의 두개골막, 천문의 섬유막층과 두피의 심부 근막층에서 발생하 는 섬유모세포 기원의 종양이라 기술하였다. 두개 근막염은 진성 종양(true neoplasm)으로 분류되지는 않으나, 빠른 성장 속도와 주변 구조물을 파괴하는 특징을 갖고 있으므로 소아 의 육종성 종양인 섬유육종, 횡문근육종과 감별을 요한다. ${ }^{2)}$

두개 근막염에 대한 기존 보고로는 국외에는 일부 보고가 있으며, 국내에는 치료적 목적이 아닌 절개생검을 통한 병리 학적 진단만을 시행한 2예만이 보고될 정도로 드물다. ${ }^{3,4)}$ 이에 저자들은 우측 코얼굴이음부에 발생한 종물을 주소로 내원 한 2세 여아에서 두 차례의 구순하 접근법을 통한 내시경 종
양 절제술 이후 추적관찰 중인 두개 근막염 1 예를 문헌고찰 과 함께 보고하는 바이다.

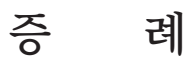

20 개월 여자 환아가 내원 약 3개월 전부터 인지된 우측 코 얼굴이음부 종물과 동측 비폐색을 주소로 3차 병원 이비인후 과에 방문하였다. 종물은 지난 3개월간 점점 커지는 양상이 었고, 본원 방문 수주 전 타 병원에서 절개를 통한 조직검사 만 시행한 상태로 두개 근막염 소견을 듣고 내원하였다. 내원 시 시행한 이학적 검사에서 우측 코얼굴이음부의 돌출이 관 찰되었으며(Fig. 1A), 동측 비강은 폐쇄된 소견을 보였다(Fig. 1B). 구강 내 검진상 동측 제일대구치 치은의 돌출이 관찰되 었다(Fig. 1C and D).

코곁굴 전산화단층촬영상 주변 조직과 불명확한 우측 뺨 에 $2.6 \times 3.6 \mathrm{~cm}$ 크기의 종괴와 우측 상악동벽, 이상구, 제일대 구치 치조와, 안와하벽의 골 파괴가 관찰되었다(Fig. $2 \mathrm{~A}$ and 

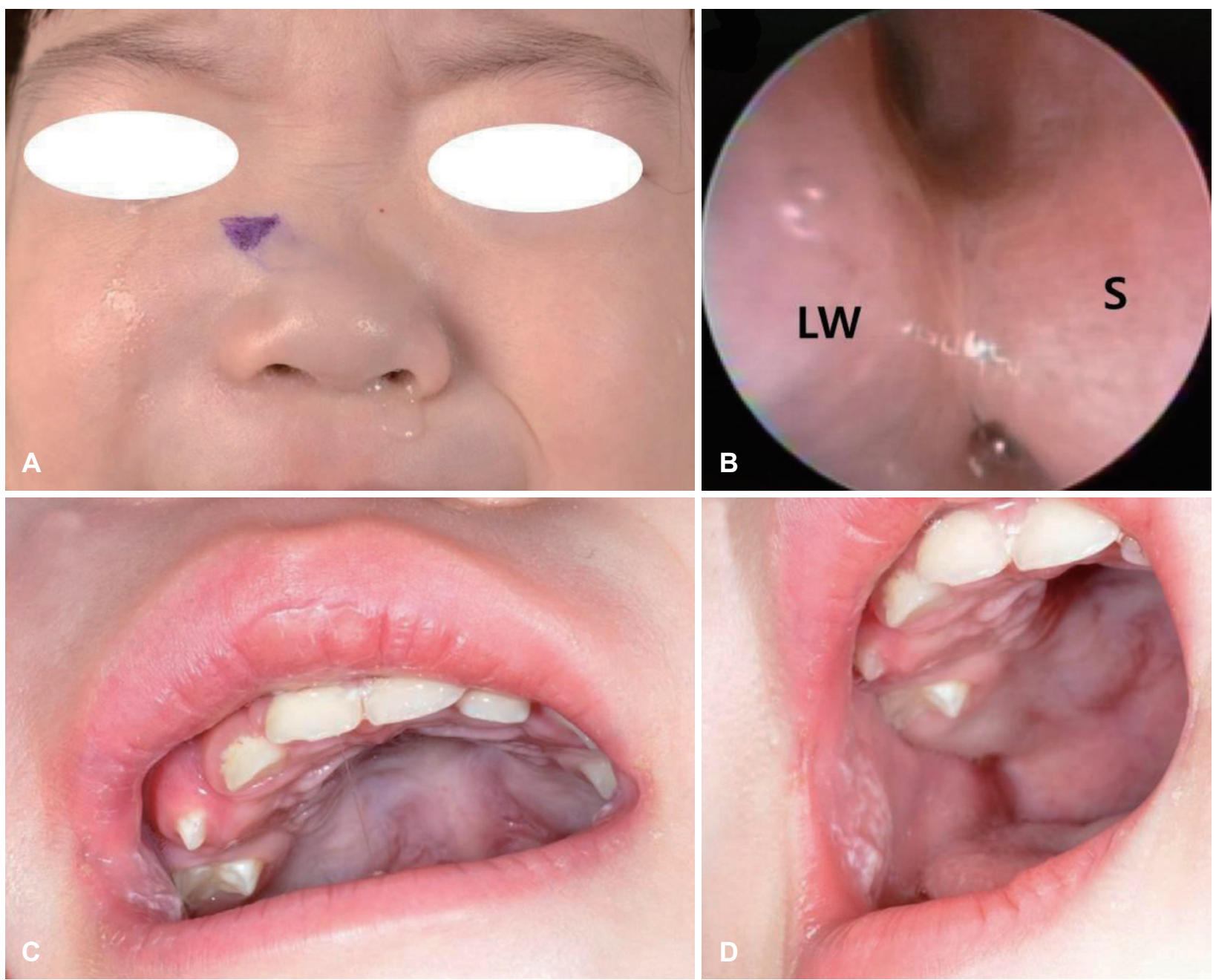

Fig. 1. A photo at the eighteen days before operation shows bulging of right nasofacial junction (marked purple arrow) (A). Endoscopic examination reveals obstructed ipsilateral nasal cavity due to lateral wall protrusion. LW: lateral nasal wall, S: nasal septal wall (B). Ipsilateral first molar tooth socket and adjacent gingiva are bulged inferiorly ( $C$ and $D)$.

B). 우측 비강은 종괴에 의하여 좁아진 소견을 보였으며(Fig. $2 \mathrm{C})$, 아래로는 동측 제1대구치, 측절치의 치조와를 침범하는 종괴가 관찰되었다(Fig. 2D).

2013년 9월 9일 전신마취 하 종양절제술을 시행하였다. 구 순하 절개를 통해 종양에 접근하여 골파괴를 유발하고 있는 종양의 경계를 포함하여 내시경 하 절제를 시행하였으며, 술 후 미용상의 문제와 치아 성장을 고려하여 안와하벽, 제일대 구치 치조와를 보존하였다. 좁아진 우측 비강에 대해서는 내 측 상악을 외향골절시킨 뒤 merocel과 silastic sheet를 비강 내에 거치시킨 뒤 수술을 종료하였다.

병리조직검사 결과, 광학현미경 소견상 중등도의 세포밀도 를 보이는 방추상세포의 증식과 뚜렷한 점액양 기질을 보였 다. 횡문근종과 섬유육종을 포함한 악성 종양에서 관찰되는 방추상 세포의 유사분열상 혹은 세포학적 비전형성은 관찰 되지 않았다. 면역조직화학염색에서 육종에서 높은 양성분
획을 보이는 $\mathrm{Ki}-67$ 양성인 세포의 분획은 $5 \%$ 로 낮았고, 섬 유성 종양에서 관찰되는 CD34 염색은 음성으로 최종 두개 근막염으로 진단되었다(Fig. 3).

수술 후 3주째 시행한 전산화단층촬영상 종양의 대부분은 제거된 상태로, 코막힘 및 코얼굴이음부 돌출 모두 호전된 소 견을 보였으나(Fig. 4A and B), 수술 후 4개월째 우측 코막힘 과 안면부 돌출이 다시 악화되어 시행한 전산화단층촬영(Fig. $4 \mathrm{C}$ and D) 및 자기공명영상(Fig. 4E and F)에서 인접한 치조 골 및 이상구의 광범위한 골파괴가 동반되었다.

이에 대해 수술 후 4개월째 전신마취 하 구순하 절개를 통 한 내시경 종양절제술을 다시 시행하였다. 재수술 당일 종양 은 치조골 및 안와하벽 주변의 종양재발이 관찰되었으며, 미 용상의 문제를 유발하지 않는 범위 내에서 제거하였다. 병리 조직검사 결과 첫 수술시와 동일한 방추상세포의 증식을 보 이는 두개 근막염 소견을 보였다. 재수술 후 4개월째 시행한 
전산화단층촬영상 코얼굴이음부의 골파괴를 유발하는 잔여 종양으로 추정되는 조영증강되는 병변이 관찰되었으나(Fig. $5 \mathrm{~A}$ and $\mathrm{B}$ ) 그 크기가 작고 안면부 돌출 없이 유지되고 있었 다. 그러나 1 년째 시행한 자기공명영상에서 병변이 광대활 부 분까지 범위가 증가한 상태로(Fig. $5 \mathrm{C}$ and D), 재수술시 완전 절제가 어렵고, 현재 외형적인 변화가 크지 않으며(Fig. 5E), 병 변의 자라는 속도가 이전에 비하여 현저히 줄어든 것으로 판단
하여 추가적인 치료 없이 외래 추적관찰 중이다.

\section{고 찰}

두개 근막염은 심근막, 골막, 두개골의 섬유막층에서 발생하는 드문 가성육종성(pseudosarcomatous) 병변으로, ${ }^{5)}$ 1980년 Lauer 와 Enzinger ${ }^{1)}$ 에 의해 처음으로 9예가 보고되었다. 발병 초기
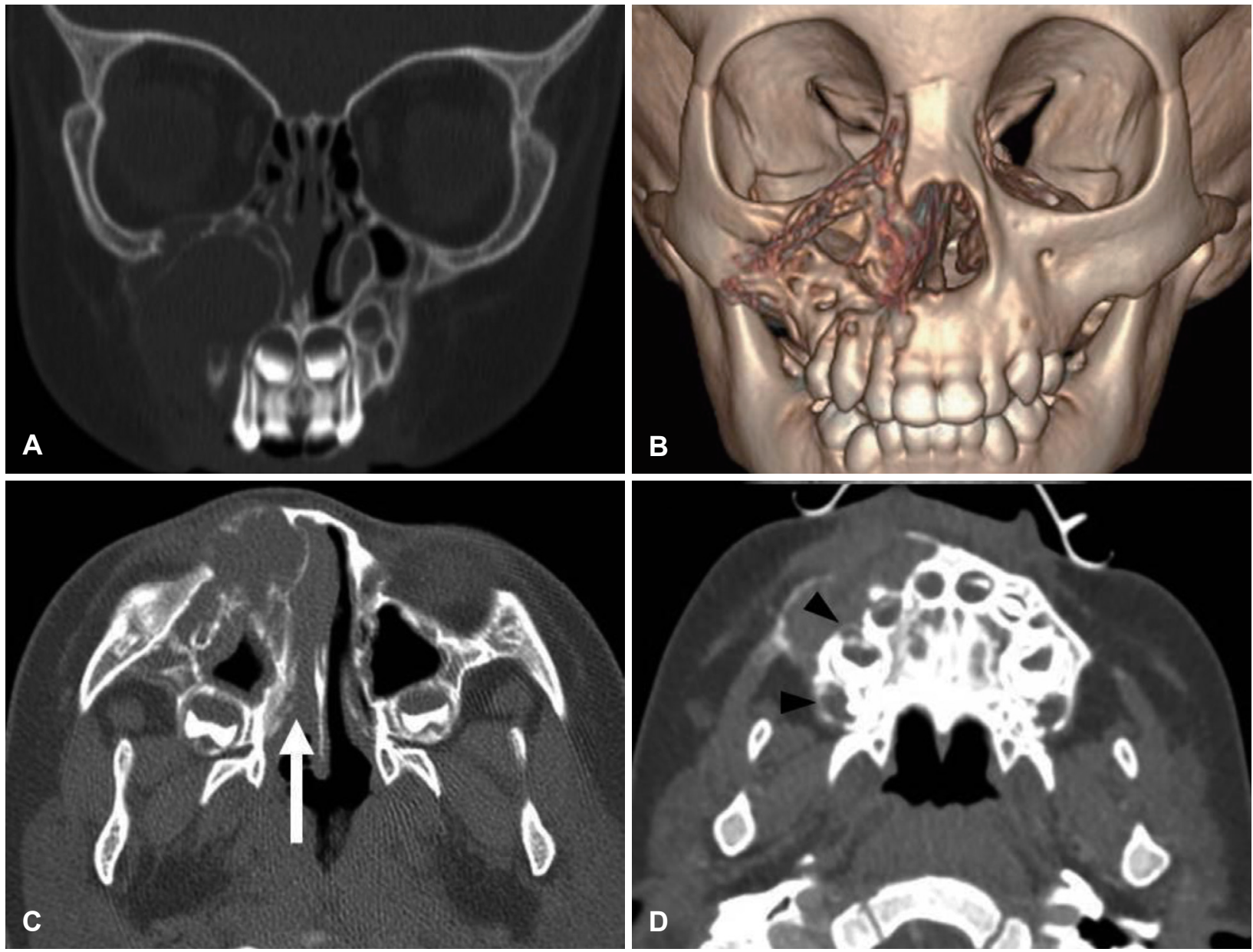

Fig. 2. Preoperative non-enhancing coronal $(A)$ and 3-dimensional $(B)$ computed tomography scan reveals ill defined mass with adjacent destruction of inferior orbital wall, maxilla, and pyriform aperture. Axial computed tomography reveals mass bulging toward the nasal cavity, causing obstruction (white arrow) (C). The mass involves first molar and canine dental socket (black arrowheads) (D).
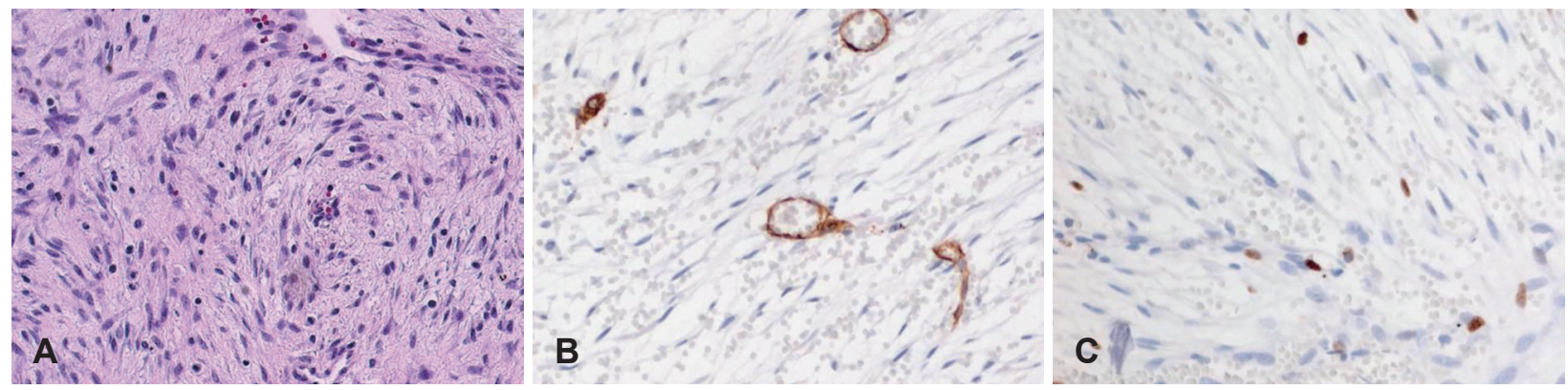

Fig. 3. The mass shows spindle-shaped fibroblasts arranged in a haphazard way within a myxoid stroma $(H \& E \times 200)(A)$, no cellular immunoreactivity was found for CD34 antigen $(\times 200)(B)$. The number of Ki-67-positive cells is low $(5 \%$ of the tumor cells $)(\times 200)(C)$. 
에는 빠른 성장을 보이지만 수개월 이내에 그 성장이 안정화 되는 양상을 보이며, 발병연령은 평균 18 개월이며, 남녀 $2: 1$ 의 발병비율로 남아에서 호발하는것으로 알려져 있다. ${ }^{1)}$ 주로 두피 중 측두부, 두정부에 호발하며, 드물게 외이도, 안구에 발생한 사례도 보고된 바 있다. ${ }^{6,7}$

침범 부위에 따라 안구돌출, 복시, 시각신경유두부종 등 안구증상을 포함하여 두개 내 침범시 발작, 안면신경마비를 유발하는 경우도 있다. 측두부에 발생한 경우 드물게 이통, 이
루, 삼출성 중이염을 유발하는 경우도 보고된 바 있다.

발병기전은 명확하지 않으나, 외상에 의한 국소적 염증반 응에 의한 것이라는 가설이 있으며,9) 후두하두개골절제술 후 발생한 2예가 보고된 바 있으며, 수술 후 14 개월, 24개월째에 해당 수술 부위에서 발생하였다. ${ }^{10)}$ 병리학적으로는 젊은 성인 의 상지에 호발하는 연조직 병변인 결절성 근막염과 조직학 적으로 동일하나, 발생 부위와 호발연령에서 차이를 보인다.

방사선학적 소견은 컴퓨터단층촬영에서는 비특이적인 골미
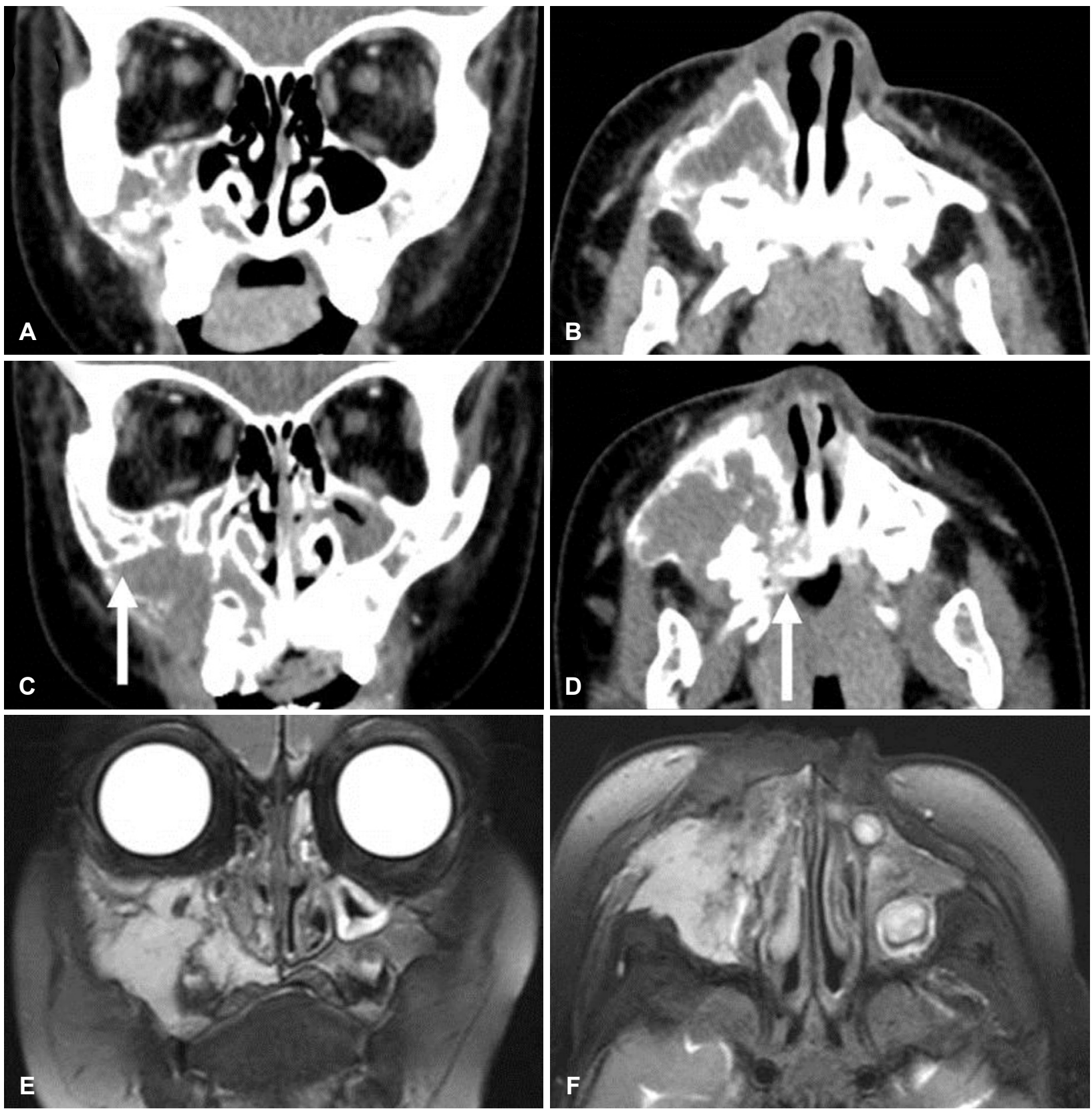

Fig. 4. Postoperative two week coronal $(A)$ and axial $(B)$ computed tomography reveals near totally removed tumor in maxillary sinus. Postoperative four month coronal (C) and axial (D) computed tomography shows accelerated destruction of adjacent bony destruction (white arrows). Postoperative four month coronal (E) and axial (F) T2 weighted magnetic resonance image shows hyper-intense recurrent lesion in maxillary sinus and adjacent bony structures. 
란과 골파괴를 보여 진단적 가치가 낮으나, 자기공명영상에서 는 $\mathrm{T} 1$ 강조 영상에서 낮고 $\mathrm{T} 2$ 강조 영상에서 높은 신호강도 를 보이며, 괴사나 출혈이 동반된 경우 불균질한 신호강도를 보인다. ${ }^{11)}$ 본 사례에서는 첫 수술 후 4개월 후 촬영한 자기공 명영상 T2 강조 영상에서 괴사조직을 동반하지 않아 비교적 균질한 신호강도를 보였다.

하지만 빠른 성장속도 때문에 소아에서 발생할 수 있는 악
성 종양과 감별을 요하므로, 생검을 통한 조직학적 확진이 진 단에 가장 중요하다. ${ }^{2}$ 전형적인 두개 근막염은 병리학적으로 결절성 근막염과 동일하며, 방추상세포의 증식과 점액양 기 질을 바탕으로 하며 낮은 유사분열률을 보이며, 이형성 세포 는 관찰되지 않아야 한다. ${ }^{12)}$ 또한, 조직학적 감별진단으로는 고립성 섬유성 종양, 소아에서 발생하는 섬유육종, 횡문근육 종 등 악성 종양이 포함되어야 한다. ${ }^{12)}$ 악성 종양과의 감별을
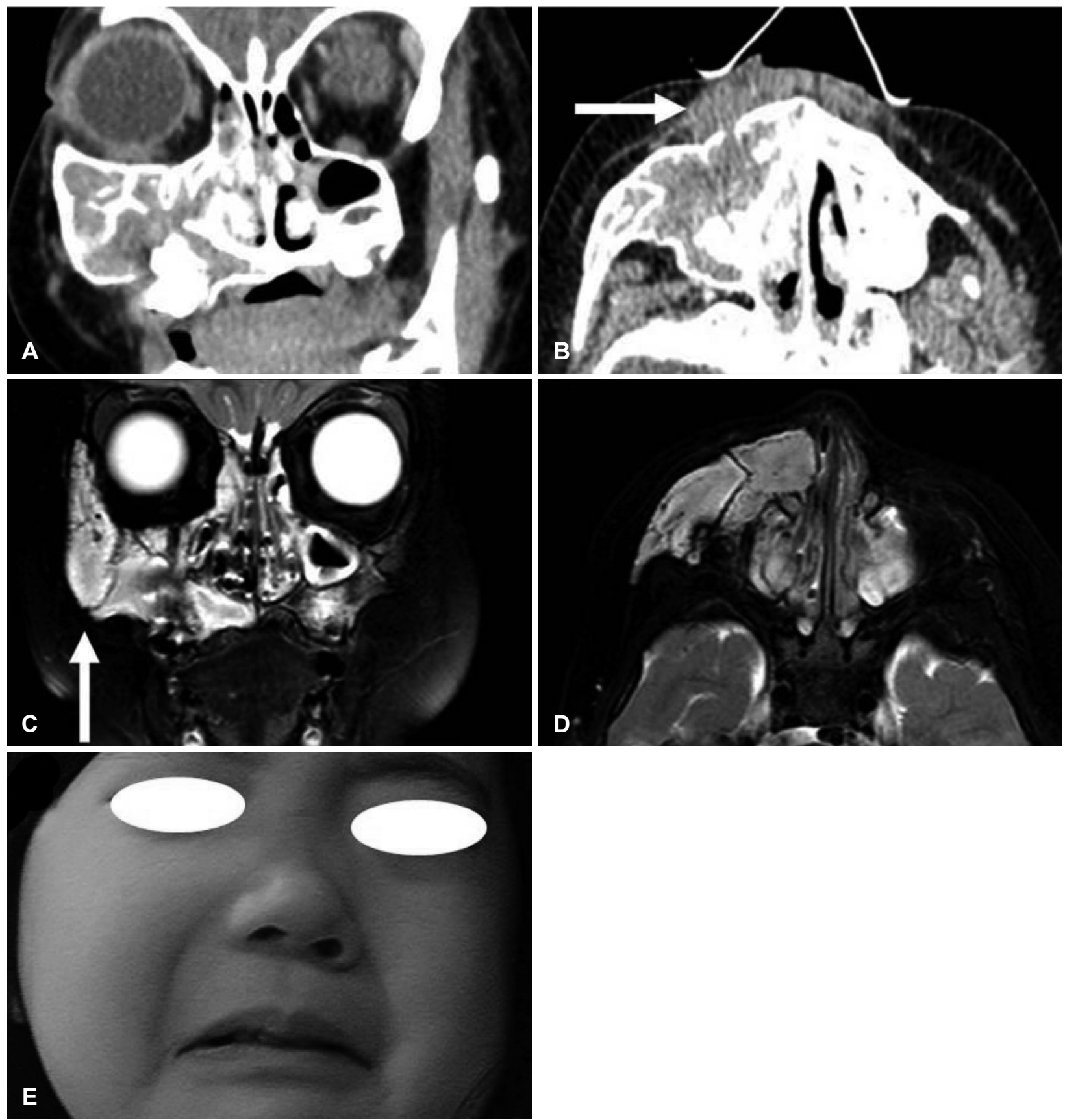

Fig. 5. Post-reoperative four month coronal (A) and axial (B) computed tomography shows minimal enhancing soft tissue lesion adjacent to nasolabial angle (white arrow). Post-reoperative one year coronal (C) and axial (D) T2 weighted magnetic resonance image shows increased extent of hyper-intense lesion around maxilla and zygomatic arch (white arrow). Post-reoperative one year photos show bulging contour of nasofacial angle and zygomatic arch (E). 
위하여 S-100, HHF35, myogenin 면역조직화학염색이 이용 될 수 있다. ${ }^{13)}$

본 사례에서는 면역조직화학염색 없이도 전형적인 두개 근 막염 소견을 보였으나, 고립성 섬유성 종양과의 감별을 위하 여 CD34 면역조직화학염색을, 악성 종양과의 감별을 위하여 유사분열 표지자인 Ki-67 면역조직화학염색을 적용하였으 며, 최종적으로 두개 근막염으로 진단할 수 있었다. 본 사례 에서는 시행하지 않았으나, 두개 근막염에서 양성을 보이는 anti-vimentin, smooth muscle actin, anti-muscle specific actin 면역조직화학염색 추가 시행을 고려할 수 있었을 것으 로 보인다. ${ }^{14,15)}$

이와 같이 병력 및 임상 소견이나, 방사선학적 검사로는 특 징적인 소견을 나타내지 않아 악성 종양과의 감별이 어렵기 때문에 수술을 통한 병리조직학적 소견으로만 정확한 진단 이 가능하며, 본 증례에서도 종물과 비특이적인 골파괴와 특 별한 임상증상 및 영상학적 특이소견 없이 외과적 생검을 통 한 병리조직학적 소견으로 진단할 수 있었다.

두개 근막염의 치료는 명확하게 정립되어 있지 않으나 초 치료는 수술적 전절제 혹은 근전절제술을 기반으로 하며, 침 범된 골침범이 있는경우 침범된 골을 포함하여 절제하는 것 을 고려해야 한다. ${ }^{6,70)}$ 하지만, 여러 가지 치료경과에 대한 보 고들이 이루어지고 있다. 가령, 18 개월 남아의 두피에 발생한 두개 근막염에 대해 침범된 골제거 없이 절제생검을 통해 연 조직 병변만 제거한 뒤 재발하여 침범된 골 제거 뒤 9개월째 관해에 도달한 사례가 보고된 바 있으며 반대로 광범위한 골 파괴와 두개내로의 침범이 동반된 경우에도 불충분한 절제 이후 자발성 퇴축된 사례도 보고되고 있다.) 또한, 두피에 발 생한 병변에 대해 병변내 스테로이드 주입 후 3 주 이내 관해 에 도달한 사례도 보고된 바 있다. ${ }^{13)}$

이와 같이 단순 경과관찰부터 근치적 전절제까지 다양한 치료경과가 보고되고 있고, 치료방침에 대한 합의가 이루어 지지 않고 있는 점을 감안하여 치료방침을 결정해야 할 것으 로 사료된다. 대부분 만 2 세 전후로 발생하며 빠른 성장과 파 괴를 동반하므로 병변의 진행에 따른 주변 구조물의 파괴뿐 만 아니라, 수술을 통한 절제에 따르는 변형 역시 고려되어야 한다. 본 사례에서는 병변의 성장에 따른 비강의 물리적인 폐색과 치조골 침범에 따른 치아 성장의 저하, 안구벽 침범에 따른 증상 발생이 우려되는 상황이었다.

따라서, 본 사례에서는 수술 후 발생할 수 있는 변형과 안 구 합병증, 치아 성장을 고려하여 침범한 인접골에 대한 전절 제가 아닌 근전절제를 시행하였으며, 수술 후 짧은 기간에 재발하여 가속된 골파괴를 보였다. 안면부 변형의 가능성과 골파괴의 진행을 막고 악성 종양의 감별을 위하여 재수술을
시행하였다. 이와 같이 발병 이후 성장속도와 자발성 퇴축의 시기를 예측하기 어렵기 때문에, $\mathrm{Oh}$ 등')은 단순 경과관찰보 다는 전절제가 불가능하더라도 근전절제를 통해 골파괴와 종양 성장에 따르는 주변 구조물의 파괴를 막아야 한다고 기 술하고 있다.

하지만 본 사례에서는 기존 보고들과 달리 첫 발병 이후 20 개월이 경과하였고, 두 차례의 근전절제를 시행하였음에 도 불구하고 그 크기가 증가하는 경과를 보이고 있다. 이는 앞서 언급한 두개 근막염의 전형적인 자연경과와 상이한 양 상을 보인다.)

본 사례에서와 같이 근전절제 후 반복되는 재발이 있는 경 우 치료방침에 대해서는 합의가 이루어지지 않고 있으며, 수 술 후 병변의 진행에 의한 변형이 유발된 사례 역시 보고된 바가 없다. 특히 빠른 성장과정에 있는 만 18 개월 전후의 환 자군이 가장 많은 만큼, 재발한 환자에 대한 치료적 합의가 시급할 것으로 보인다. 본 사례에 근치적인 절제를 시행할 경 우 상악골, 이상구, 치조골을 모두 포함한 상악절제술이 필요 한 상태이며, 환아의 연령과 향후 성장을 감안할 때 광범위 한 절제는 미용적, 기능적 손실이 수술에 의한 이득을 넘어 설 것으로 판단되었다.

따라서, 두 차례의 수술에서 모두 병리학적으로 전형적인 두개 근막염 소견을 보여 악성 종양을 포함한 다른 질환이 배 제되었고, 자연퇴축에 이르는 자연경과를 고려하여 안구 및 안면부 변형, 치조골 침범에 따르는 증상을 평가하며 추가적 인 수술 없이 추적관찰 예정이다.

이와 같이 안면부에 발생한 두개 근막염의 경우 병변 크기 증가에 따른 증상 발생과 수술 후 발생할 수 있는 합병증을 저울질하여 절제범위를 설정해야 하며, 술 후 짧은 기간 내 재발한 경우 추가적인 안면부 변형을 막고 정확한 병리학적 재평가를 위한 추가적인 수술을 고려해야 할 것으로 판단된 다. 또한, 방사선학적 재발이 확인되는 경우, 수술에 의한 안 면부 변형 가능성을 고려하여 수술 시기를 결정해야 할 것으 로 보인다.

\section{REFERENCES}

1) Lauer DH, Enzinger FM. Cranial fasciitis of childhood. Cancer 1980;45(2):401-6.

2) Yiu Y, Chiang T, Lovell MA, Chan KH. Nasal congestion and a rapidly enlarging mass at the nasofacial junction. JAMA Otolaryngol Head Neck Surg 2013;139(9):953-4.

3) Ahn KS, Je BK, Kim YS, Kim TK, Kim BH, Cha SH. Nodular Fasciitis on the Nasolabial Fold in a 5-month-old Infant: a case report. J Korean Radiol Soc 2006;55(6):623-7.

4) Jang HS, Lim GY, Lee EJ, Lee KY. Cranial Fasciitis in a Child: a case report. J Korean Radiol Soc 1999;40(4):801-4.

5) Adler R, Wong CA. Cranial fasciitis simulating histiocytosis. J Pediatr 1986;109(1):85-8. 
6) Lang DA, Neil-Dwyer G, Evans BT, Sarsfield P, Nenji E. Cranial fasciitis of the orbit and maxilla: extensive resection and reconstruction. Childs Nerv Syst 1996;12(4):218-21.

7) Clapp CG, Dodson EE, Pickett BP, Lambert PR. Cranial fasciitis presenting as an external auditory canal mass. Arch Otolaryngol Head Neck Surg 1997;123(2):223-5.

8) Lecavalier M, Ogilvie LN, Magee F, Poskitt KJ, Kozak FK. Cranial fasciitis: a rare pediatric non-neoplastic lesion with 14-year follow up. Am J Otolaryngol 2014;35(5):647-50.

9) Oh CK, Whang SM, Kim BG, Ko HC, Lee CH, Kim HJ, et al. Congenital cranial fasciitis--"watch and wait" or early intervention. Pediatr Dermatol 2007;24(3):263-6.

10) Summers LE, Florez L, Berberian ZJ, Bhattacharjee M, Walsh JW. Postoperative cranial fasciitis. Report of two cases and review of the literature. J Neurosurg 2007;106(6):1080-5.
11) Johnson KK, Dannenbaum MJ, Bhattacharjee MB, Illner A, Dauser RC, Whitehead WE, et al. Diagnosing cranial fasciitis based on distinguishing radiological features. J Neurosurg Pediatr 2008;2(5): 370-4.

12) Yébenes M, Gilaberte M, Romaní J, Lloreta J, Pujol RM. Cranial fasciitis in an 8-year-old boy: clinical and histopathologic features. Pediatr Dermatol 2007;24(4):E26-30.

13) Lee JY, Kim YC, Shin JH. Cranial fasciitis treated with intralesional corticosteroids. Int J Dermatol 2004;43(6):453-5.

14) Sarangarajan R, Dehner LP. Cranial and extracranial fasciitis of childhood: a clinicopathologic and immunohistochemical study. Hum Pathol 1999;30(1):87-92.

15) Patterson JW, Moran SL, Konerding H. Cranial fasciitis. Arch Dermatol 1989;125(5):674-8. 